\title{
Rethinking Home-School Partnerships: Lessons Learned from Latinx Parents of Young Children During the COVID-19 Era
}

\author{
Lucinda Soltero-González ${ }^{1} \cdot$ Cristina Gillanders $^{1}$
}

Accepted: 14 May 2021 / Published online: 1 June 2021

(c) The Author(s), under exclusive licence to Springer Nature B.V. 2021

\begin{abstract}
The COVID-19 pandemic has greatly impacted families from low-income backgrounds. The shift to remote learning has required parents with preschool-age children to adapt to new ways of collaborating with teachers. Given the longstanding inequities in the education of children from economically disadvantaged backgrounds, exacerbated by the pandemic, it is critical to learn about the challenges that parents encountered and how they supported their children's learning. This knowledge will help to identify ways to better serve these communities during times of crisis and beyond.

This study examined how Latinx parents from low-income backgrounds engaged in their children's early education during the COVID-19 crisis. The term Latinx is used in an effort to be gender inclusive when referring to people of Latin American descent. We explored: 1) How do Latinx parents perceive and apply teachers' suggested activities to support children's learning during the early childhood education program closure? 2) What parent and child-initiated learning opportunities do parents report? 3) What challenges with remote learning do parents encounter? Twenty parents of preschoolers in a mountain state metropolitan area participated in a 30-45 min. phone interview. All parents spoke Spanish at home to a different degree. Findings revealed the emergence of more authentic parent-teacher partnerships and parents' extensive engagement in teacher-suggested activities. Importantly, families created a variety of practices to support children's learning and wellbeing. Yet, a vast majority of parents expressed feeling stressed with the demands of remote education, particularly keeping their child interested in remote learning. Implications for home-school partnerships are discussed.
\end{abstract}

Keywords Home-school partnerships · Parental engagement/involvement · Latino/latinx/spanish-speaking parents · COVID-19 $\cdot$ Early childhood education $\cdot$ Remote learning

\section{Introduction}

Many families around the world have been severely impacted by the COVID-19 pandemic. In the United States (U.S.), 36 million workers have filed unemployment insurance (Berube 2020). A group that has been particularly affected is Latin $x^{1}$ families from low-income backgrounds (Krostad \& Lopez 2020). The closure of schools and early childhood education programs (ECE) along with current social distancing measures to mitigate viral spread have forced children and parents to adapt to new early education environments. According to the Rapid-EC survey (2020)—an

Lucinda Soltero-González

Lucinda.soltero-gonzalez@UCDenver.edu

1 School of Education and Human Development, University of Colorado Denver, 1380 Lawrence St, Denver, Colorado, USA ongoing survey of representative households with children from birth to 5 years old $-47 \%$ of families lost childcare and $60 \%$ of parents whose children were enrolled in center-based programs became the main childcare provider. As a result, parents have had to assume the role of ECE educators. Key to this transition to remote learning has been the collaboration between ECE teachers and parents. The current unusual situation offers an opportunity to develop a deeper understanding of the beliefs and practices of Latinx parents from low-income backgrounds to promote children's learning and how this can inform home-school partnerships.

\footnotetext{
"We use the term Latinx (pronounced "Latin-ex"), whose use has increased in the U.S. in the last decade, in an effort to be gender inclusive when referring to people of Latin American descent. We recognize that members of Latin American descent communities may not always use or agree with this term. In this study, we acknowledge the self-disclosed ethnicity of our participants; at the same time, we use the term Latinx as an alternative to the ethnic category traditionally known as Latino, which conveys a masculine-centric connotation in the Spanish language.
} 
Concerns about the adverse effects of ECE program closures on children are magnified when considering the longstanding inequities in the education of Latinx children and families in the U.S., especially those from low socio-economic backgrounds. Deficit views of Latinx families have prevailed in early childhood settings, where the languages, literacies, and cultures of children and Latinx communities are viewed as deficiencies to be overcome in order to succeed academically and socially. In turn, Latinx families are socialized to acquire the monolingual, White-middle class norms that are legitimated in school, often at the expense of their cultural and language practices (Paris 2012). The policies and pedagogies stemming from such deficit perspectives assume that ECE is responsible for "fixing" the perceived deficits of Latinx children and their families, disregarding the brilliance of families and Latinx children (Pérez \& Saavedra 2017). The transition to remote learning is dramatically changing home-school partnerships from the way we have know them. A parent-teacher relationship that validates families' funds of knowledge (Moll et al. 1992), including their cultural and language practices, is needed more than ever. In contrast to the traditional supporting role of parents, the situation requires that parents create a home learning environment while assuming the role of main facilitator of their children's learning. This necessitates both teachers and parents to adapt quickly and embrace new ways of collaborating with one another to support children's learning progress.

Strengthening home-school partnerships has been touted as a way to address the discontinuities between home and school in Latinx children and families. In the times of COVID-19, this claim has become more than an aspiration as ECE programs now depend on parents to promote children's development.

Given the demands of remote learning, it is critical to learn more about how parents draw on their cultural resources and knowledge to cope with the challenges they may encounter in their children's education. This will help to identify ways to better serve this population during times of crisis and beyond. Learning more about what parents are actually doing and what resources they need can inform the design of more culturally sustaining approaches (Paris 2012) for home-school partnerships. Culturally sustaining pedagogy promotes and sustains children's and families' skills and knowledge and gives children and families opportunities to acquire the knowledge and skills needed to succeed in school (Paris 2012). So rather than only being responsive to families' cultural practices, culturally sustaining approaches affirm the strengths of these practices. This study sheds light on ways to disrupt inequities within ECE and counter deficit ideologies about the cultural practices of Latinx families.

The purpose of this study was to learn more about how Latinx parents from low-income backgrounds are supporting their children's early education during the COVID-19 crisis. We explored the remote learning support that parents received from educators and how they perceived and applied teachers' suggestions at home. Moreover, we examined how parents initiated other activities that reflected their beliefs about how children learn. Finally, we explored the challenges parents encountered with their children's remote learning.

\section{Literature Review}

Sociocultural theories of human development guide the examination of the ways Latinx parents orchestrate children's learning and development opportunities (Rogoff 2003). We draw upon these theories to better understand the sociocultural contexts where young Spanish-speaking children participate as well as how families interpret the teachers' intentions and their own role as children's first teachers (Mistry et al. 2016). Efforts to create home-school partnerships aiming to minimize the discontinuities that might exist between families' and school's beliefs about each other's expectations and practices should consider the "cultural models" and "cultural settings" where children engage (Gallimore \& Goldenberg 2001). Gallimore and Goldenberg (2001) define cultural models as the shared ways of thinking and interpreting how the "world works or, ought to work" (p. 47) and cultural settings as "those occasions where people come together to carry out joint activity that accomplishes something of value" (p. 48). Examining parents' interpretation and enactment of ECE practices at home during COVID will allow us to uncover Latinx parents' cultural models and settings.

Previous research concludes that when parents are meaningfully involved in their children's schooling, children demonstrate better educational and mental health outcomes (Jeynes 2003; Smith et al. 2020). Through meaningful parental engagement, parents gain a better understanding of schools' cultural models and settings. A construct that encompasses the cultural models and settings connected with schools has been also referred to as academic socialization. This construct refers to parental beliefs (cultural models) and practices (cultural settings) to create contexts in which children learn behaviors, attitudes, and social skills useful for their development in school (Puccioni 2018; Taylor et al. 2004).

Academic socialization varies among parents depending on their own experiences in school, their ideas about what is expected from school, and their own beliefs about how children learn (Davis et al. 2016; Lynch et al. 2006; Taylor et al. 2004). Previous studies on parents' academic socialization with regards to literacy reveal that some Mexican-American parents tend to believe that reading is learned through a 
formal process and involves putting syllables together (Reese $\&$ Gallimore 2000). Parents' beliefs are influenced by their own experiences learning to read and are reminiscent of traditional forms of teaching reading in Latin America (Reese $\&$ Gallimore 2000). Because many of these parents have not attended school in the U.S., they are less familiar with the expectations in ECE programs (Sonnenschein et al. 2018).

Extensive literature highlights that Latinx parents have high educational expectations for their children (e.g., Sonnenschein \& Galindo 2015; Suizzo et al. 2014) and engage in practices in the home that, although beneficial for children's development, might not be congruent with those used in school (Gillanders \& Jiménez 2004; Rodriguez 2006; Sonnenschein \& Galindo 2015). However, cultural models are not static and as immigrant parents participate in their children's schooling, parents dynamically integrate ideas of what they perceive is expected in U.S. schools (Gillanders \& Jimenez 2004; Reese \& Gallimore 2000). For example, Gillanders and Jimenez (2004) found that although reading aloud is not a common practice in Latinx households, parents in this study tended to integrate it into their repertoire of practices as soon as teachers emphasize its importance.

Finally, parental academic socialization is also influenced by parents' beliefs about how children learn. Sonnenschein and colleagues (1997), for example, found that some parents hold either an entertainment or skills-based approach to teach their children about literacy. Parents with an entertainment perspective tended to be more responsive to the child's interests and experiences with print. In contrast, parents with a skills-oriented perspective tended to believe that children learn better through direct instruction and more frequently used flashcards and workbooks. Sonnenschein et al. (1997) also found that most parents from low-income backgrounds in her sample had a skills-oriented perspective. In a more recent study of parents' beliefs about teaching mathematics to their children, Sonnenschein et al. (2018) reported that half of the Latinx parents in their sample believed that children learn mathematics through play while a third believed that children learned through practice.

In general, previous studies have found variability in the academic socialization of Latinx families with young children (Davis et al. 2016). From families who seldom read and discuss picture books to their children and are uncertain about the value of reading aloud, to families who often engage their children in school-related skills (Davis et al. 2016), Latinx families living on a low-income vary in the ways they create cultural settings for their children's academic socialization. During the COVID-19 crisis, many parents bear sole responsibility for their children's early education, so it is crucial to learn more about parental engagement in the learning activities suggested by teachers. We were also interested in examining how parents might change the ways they create opportunities for academic socialization given the conditions created by COVID- 19 .

This study was guided by the following research questions: 1) How do Latinx parents from low-income backgrounds perceive and apply teachers' suggested activities to support children's learning during the ECE program closure? 2) What parent and child-initiated learning opportunities do parents report?, and 3) What challenges with remote learning do parents encounter?

\section{Methods}

The present qualitative study used demographic questionnaires and semi-structured interviews. We partnered with the Denver Preschool Program (DPP), a non-profit organization under a contract with the City and County of Denver that provides sliding scale tuition assistance for all Denver families, regardless of income or neighborhood. Families can choose from more than 250 participating preschools in Denver. Currently, DPP is serving approximately 1,830 children from Spanish-speaking households who represent $40 \%$ of all the children attending a preschool within DPP.

\section{Recruitment and Participants}

DPP staff provided us with a database of 184 potential families who spoke a language other than English at home. Families who did not speak Spanish at home, had children who only attended an after school program or reported high socioeconomic status were excluded from participation. We selected participants from community-based programs with the highest number of Latinx families. From this list, we contacted 36 parents from Spanish-speaking households with a child attending Head Start or a community-based program, as we were especially interested in families with a low socioeconomic designation. All children were between 3 to 5 years old and attended preschool 5 days a week.

DPP community-based program directors received an email from a DPP staff introducing the researchers and advising directors that the researchers would be contacting parents directly. The researchers sent an email to parents introducing themselves, their affiliation with the university, and explaining the purpose of the study. The researchers followed up with a text message that included an informational flyer inviting parents to participate in a phone interview. They called by phone those parents who had not answered the text message. Parents were offered a $\$ 50$ gift e-certificate as a token of appreciation for their participation. The study was submitted to the university Institutional Review Board (IRB) to which the researchers are affiliated and the study was determined to be exempt from full IRB review. 
Table 1 Demographic Characteristics of Participants ( $\mathrm{N}=20$ parents)

\begin{tabular}{|c|c|c|c|}
\hline Variables & & Frequency & $\%$ \\
\hline \multirow[t]{3}{*}{ Relationship with child } & Mother & 18 & 90 \\
\hline & Father & 1 & 5 \\
\hline & Grandmother & 1 & 5 \\
\hline \multirow[t]{4}{*}{ Parents' Ages } & $20-25$ & 1 & 5 \\
\hline & $25-35$ & 9 & 45 \\
\hline & $35-45$ & 9 & 45 \\
\hline & $45-55$ & 1 & 5 \\
\hline \multirow[t]{3}{*}{ Country of Birth } & Mexico & 12 & 60 \\
\hline & US with Mexican Heritage & 7 & 35 \\
\hline & Central America & 1 & 5 \\
\hline \multirow[t]{3}{*}{ Years in the United States } & 10-20 years & 7 & 35 \\
\hline & $20-30$ years & 9 & 45 \\
\hline & $30-40$ years & 4 & 20 \\
\hline \multirow[t]{5}{*}{ Highest Educational Level } & Some or completed elementary & 2 & 10 \\
\hline & Some Middle School/High School & 5 & 25 \\
\hline & Completed High School & 9 & 45 \\
\hline & Some College & 3 & 15 \\
\hline & Completed College & 1 & 5 \\
\hline \multirow[t]{3}{*}{ Parent language use at home } & English Only & 1 & 5 \\
\hline & Spanish Only & 12 & 60 \\
\hline & Both Languages & 7 & 35 \\
\hline \multirow[t]{3}{*}{ Language use at school } & English Only & 6 & 30 \\
\hline & Spanish Only & 4 & 20 \\
\hline & Both Languages & 10 & 50 \\
\hline \multirow[t]{3}{*}{ Occupation } & Housewife & 11 & 55 \\
\hline & Low paid service work & 7 & 35 \\
\hline & College education profession & 2 & 10 \\
\hline
\end{tabular}

A total of 20 participants were interviewed, including 18 mothers, 1 father, and 1 grandmother during the months of June through August of 2020. Four of the mothers in our sample were recruited through snowball sampling; we asked interviewees to recommend other parents from Spanish-speaking households with children 3 to 5 years of age who attended preschool. These 4 parents had children in pre-K classrooms in a public elementary school. All parents indicated that the ECE program their children attended was closed between March and May of 2020 and parents were in contact with their teachers through a variety of methods (see Findings). Ten of the ECE programs employed English and Spanish as the language of instruction, 6 used only English, and 4 used only Spanish.

Eighteen mothers, 1 father, and 1 grandmother participated in the study. The majority of the parents were 25-45 years old (see Table 1). Most parents were born in Mexico, 7 were born in the U.S. and self-identified as having Mexican heritage, and one parent was born in a Central American country. All parents had more than 10 years living in the U.S. Only one parent had a college degree, 9 had completed high school, and 7 had less than a high school education. Eleven participants who were mothers did not work outside of the home, while 10 other mothers who participated did work outside of the home. Twelve parents spoke only Spanish at home, 7 spoke both Spanish and English, and 1 spoke only English but the child's father spoke Spanish at home. We obtained information about the socioeconomic status of the 16 parents in our sample who were registered in DPP. Five families had incomes below 100\% of the federal poverty line (FPL) and $75 \%$ of families in the sample were considered low-income $(300 \%$ or below of the FPL).

\section{Procedure}

Twenty parents participated in a demographic questionnaire and a 30-45 min. interview conducted over the phone or Zoom. The partnership with DPP afforded us a considerable level of trust from potential participants and reliability of interview data. Key interview questions and alignment to research questions (RQ) are provided in Fig. S1. 
All interviews were conducted in Spanish by the two authors with the exception of 2 that were conducted in English, per participants' request. Both authors are native Spanish-speakers with advanced English proficiency and expertise in qualitative research methods. All interviews were transcribed and edited for accuracy.

\section{Data Analysis}

We developed a coding scheme following a deductive and inductive process and both researchers participated in the coding process using the Dedoose software. Dedoose is a cross-platform software for analyzing qualitative and mixed methods research with text, photos, audio, videos, spreadsheet data and more. Initial coding focused on parents' perceptions of and engagement in their child's remote learning in 3 domains: 1) types of supports received from teachers and parents' implementation of those supports (e.g., supporting child's learning), 2) parent-teacher interaction before and during remote learning, modes of delivery, and parents' views of such interactions (e.g., parents' perceptions of teacher communication), and 3) family-initiated activities supportive of child's development and challenges experienced during the pandemic (e.g., parent or child-initiated activities).

All 20 interview transcripts were coded independently by both authors. To ensure consistency in coding, all excerpts from the 20 interviews associated with 4 selected codes were exported from Dedoose to obtain an initial measure of interrater reliability. We first identified all instances of coding agreement on the excerpts linked to each of these 4 codes. Next, we calculated a percent agreement for each code by dividing the total agreement by the total count; the percent agreement for these codes was then averaged, resulting in a 53\% agreement. After discussing and resolving discrepancies, we refined our coding scheme and re-coded all the interview transcripts. Inter-rater reliability was calculated for all the excerpts tied to 4 additional codes, obtaining a 90\% agreement.

Data analysis involved the writing of analytic memos, where we grouped similarly coded interview excerpts; excerpts coded as "great quotes" were also included. The analytic memos allowed us to identify themes, make connections to theory, and maintain a chain of evidence necessary to substantiate findings (Yin 2009). Using the constant comparison method (Glasser \& Strauss 1967), each emerging theme was compared to originally identified themes, crosschecked with the interview data, and refined. Data analysis yielded three themes that are discussed next.

\section{Findings}

The semi-structured interviews focused on Latinx parents' perception and implementation of teachers' intended learning activities as well as the ways in which parents engaged their children in remote learning during the COVID-19 pandemic. We were particularly interested in documenting how parents adapted to and experienced this new way of engaging in their children's schooling and their role in it.

As a way of comparison, we asked parents to reflect retrospectively on the pre-COVID engagement in their child's education. A number of parents described receiving weekly learning packets with their child's finished work along with additional worksheets to complete at home. The material in these learning packets was in Spanish or English, depending on the ECE program (10 of the programs used both languages for instruction, 6 used only English, and 4 used only Spanish). According to parents, teachers sent these materials home regularly to inform parents of their child's progress and to provide extended practice throughout the week. Parents returned the completed learning packets directly to the teacher at the end of the weekly period. It is noteworthy that parents viewed these activities as "homework" or supplemental to school learning.

Parents reported participating before the pandemic in traditional family-school interactions in ECE (e.g., parent-teacher conferences and receiving newsletters), along with informal face-to-face communication with the teacher at school drop off and pick up. Although some teachers expected parents to submit their child's completed "homework," there was hardly any parent-teacher interaction. Yet, parents perceived the family-school connection positively and viewed it as a window into their child's learning at school.

In what follows, we describe, from the parents' perspective, how the COVID-19 pandemic has shaped the relationship among preschool teachers and Latinx families living in low-income households. First, we summarize parents' perceptions around parent-teacher collaboration alongside parents' involvement in their child's remote learning. We then depict ways in which parents engaged their children in parent- and children-initiated activities. We also provide a summary of the main challenges parents experienced with their young children's remote education.

\section{Theme 1: Parents' Perception of and Experience with Parent-Teacher Collaboration}

\section{Authentic Caring}

Parent interviews revealed changes in the frequency of parent-teacher communication and the nature of their 
relationship as compared to before the pandemic. From the start of remote learning, most teachers communicated regularly with parents and children. Although this was expected, given the transition to remote learning, parents noted an important change: the relationship with the preschool teacher morphed into a more authentic partnership. A twoway communication emerged and parents felt comfortable reaching out to teachers to seek guidance as they engaged their children in learning activities. Similarly, teachers communicated with parents more regularly asking how everyone in the house was doing.

According to parents, teachers were very supportive despite the enormous challenge of teaching young children remotely. Parents also related that teachers constantly motivated them to do everything they could to complete the activities designed to support children's learning at home. Parents appreciated teachers' guidance and encouragement, especially those who felt they lacked the ability to teach in the ways they perceived were expected by teachers.

Most parents felt that teachers were not only concerned about the curriculum but also that they genuinely cared about their child's and the family's well-being. Parents were grateful for this ongoing personal communication with the teacher during these challenging times. Teachers also made parents aware of community organizations they could contact to obtain resources such as food and clothes.

\section{Flexibility in the Modes of Communication}

Parents appreciated having the flexibility to communicate with teachers through various modes such as phone calls, text messages, and email. Parents also found it helpful to work with the teacher in establishing a schedule that would work best for them to stay connected; some families spoke fondly of teachers who called them through videoconference or sent them pre-recorded videos later in the afternoon to accommodate their work schedule.

With regards to how ECE was delivered in response to the pandemic, parents reported that educators quickly adapted to teaching remotely and regularly facilitated lessons delivered through various online platforms (e.g., Google Meet, Dojo app, Zoom). Asynchronous assignments were shared through pre-recorded videos and instructions sent via text messages, email or posted online, and in learning packets.

In addition to live teacher-facilitated lessons, teachers planned daily offline activities. In some cases, a new collaboration process was created where parents took pictures of the completed work and sent them to the teacher via text message. One of the parents described how the teacher created a WhatsApp group for the purpose of sending instructions and for parents to submit pictures of their child's work. This group facilitated communication amongst parents and expanded their support network.
In contrast to the ongoing parent-teacher interactions described above, a few parents reported no direct contact with the teacher and only received educational materials to be completed in 2 to 3 -week periods. These parents reported feeling isolated and unsupported due to the lack of interaction with the teacher and other parents.

\section{Prioritizing Children's Academic Learning}

Regardless of the delivery format, teachers primarily focused on reinforcing previously learned skills, particularly beginning literacy and mathematical skills. For example, writing their full name, practicing the alphabet, identifying the beginning letter name or letter sound of words, recalling color names, handwriting, and counting skills. Other aspects of children's development such as socio-emotional development and learning through play and inquiry-based activities were less emphasized.

When asked about their perceptions of remote learning, 13 out of 20 parents expressed agreement with the prevalent academic focus. For parents, the activities teachers suggested were helping their child to practice what they had been previously learning in the classroom and to be prepared for kindergarten. The main reasons offered by parents who were not in complete agreement with the teachers' recommended activities include hard to follow instructions, difficulty engaging the child, and an excessive amount of work that required close parental support.

\section{Parent Preferred Learning Activities}

While parents recognized the importance of reinforcing skills to get their child ready for kindergarten, the majority of parents (70\%) struggled to keep their child engaged when the activity required prolonged sit down time. Many parents reported that their child was bored even during live readalouds. Echoing a commonly held view among participants, one mother noted that her child preferred to participate in hands-on activities that looked like they were playing:

Lo que yo miré es que es más hands-on. Osea, que él haga. Él tenía que estar escuchando las historias en la computadora, pero él se aburría. Las actividades que involucraban como vamos a colorear esto, vamos a usar pintura, osea, era algo que no parecía trabajo, que parecía más como que ioh, vamos a jugar! (What I saw is that they are more hands-on. Meaning that the child is involved. He had to listen to read aloud stories on the computer but he got bored. Activities that involved like, let's color this, or let's paint, or that didn't look like schoolwork, instead, they were more like, Oh, let's play!). 
According to parents, the most beneficial activities suggested by the teacher shared the following characteristics:

Active participation and child-adult interaction (e.g., coloring, painting, sorting laundry by color and counting the number of clothes in each pile)

Learning through unstructured play (e.g., playing with Legos, playing outside)

Learning through discovery (e.g., contrasting different types of soap based on color, consistency, and shape; observing nature)

Choice (e.g., child-initiated dramatic play, describing self-selected daily experiences through writing and drawing)

\section{Theme 2: Parent- and Child-Initiated Learning Activities}

The interviews revealed a host of activities parents created to support their child's learning from home. Parents viewed many of these activities as supporting their child's learning and essential for getting their child ready for kindergarten. Other activities were considered recreational or part of their daily routines by the parents.

\section{Making Learning Fun}

From the 20 interviews conducted, 17 parents reported engaging their child in school-like activities in addition to those suggested by the teacher. Some of these parent-initiated activities were similar to the assignments that teachers recommended. For example, using workbooks, computer games, and YouTube videos to teach children about letters, numbers, shapes, sight words, and handwriting skills. Additionally, parents provided children with notebooks, pencils, and color pencils to practice writing their name. Some parents reported reading to their children, however this activity was less common.

In addition to these traditional learning activities, $75 \%$ of parents reported creating play-based opportunities, some of which supported the development of literacy and mathematical skills. One parent offered an instance of playing school with his daughter:

\footnotetext{
"Por ejemplo, le pongo las letras del abecedario en el pizarrón y ella las hace abajo y me las tiene que ir diciendo como la A en español, en mayúsculas, en minúsculas y hacemos una palabra con esa letra...a ella le gusta mantenerlo como juego, pero a la vez ella obviamente está aprendiendo." (For example, I write the letters of the alphabet on a blackboard and she copies them below, she needs to tell me the letters like the A in Spanish, in capital letters and lowercase,
}

and we make a word with that letter... she likes it to be like we're playing, but at the same time she's obviously learning)

Another parent created mathematical problems for her older daughters. Seeing her preschool child's interest, she adapted the problems for him as his siblings completed their homework. The mother turned the activity into a race to motivate her children:

"Con las niñas me gustaba darles problemas de matemáticas y él pues se sentaba ahí con ellas, pero no entendía igual como ellas y yo lo hacía como una carrera, a ver quién puede hacerlo más rápido. El que gane va a poder escoger el postre esta noche. Osea, para que sigan practicando todo lo que han aprendido." (I liked to engage my girls in solving math problems and he was sitting right there with them, but he didn't have the level of understanding his sisters had and so I turned it into a race, to see who could solve them first. The winner could choose the dessert for that night. I mean, so they can continue practicing what they have learned).

\section{Playing Together}

A number of parents reported that they needed to be creative to keep their children entertained and safe at home. In addition to completing what parents described as activities to prevent learning loss, parents made sure children had time to play outside. Children engaged in daily outdoor activities such as biking, soccer, running, and finding insects in nature.

Several parents indicated a desire to keep their children away from the TV and thus, they created interactive activities for the whole family. Parents bought puzzles, playdough, chalk, and board games to play with their children. These opportunities were not only initiated by the parents but also by the children. For example, 2 parents reported their children asking to play doctor's office and bookstore. Prompted by their dramatic play, the children asked for materials to create symbolic objects. For example, a child pretending to be a bookseller asked his mother: "Me preguntó que cómo se escribía 'abierto' y ya le fui diciendo letra por letra. $Y$ él escribió abierto, cerrado." (He asked me how to write the word "open" and I said it letter by letter. And he wrote open, closed). Another parent reported watching a children's movie with her son and then creating the main characters using playdough.

Most parents viewed these experiences merely as a way to entertain their child and prevent boredom. Describing the various activities in which they participated as a family, one mother offered:

"No me he enfocado tanto en hacer tarea, lo único es leer un ratito en las tardes porque no quiero que 
se le vaya a olvidar la lectura. Trato de entretenerlos con otros jueguitos de mesa porque no quiero que estén tanto en la tele, en el teléfono, en la tableta. Les compré una alberca chiquita. Pero en sí, de lo que es aprendizaje, nada más me he enfocado en leer un ratito en las tardes." (I haven't done much homework, the only thing we've done is some reading in the afternoon because I don't want them to forget how to read. I try to entertain them with board games because I don't want them to be all the time watching TV or on their phone or tablet. I bought a small swimming pool. But, in relation to learning, I've only done some reading in the evenings).

Although she planned activities that could be considered important for child's development such as board games and playing in the swimming pool, this mother did not consider these as learning opportunities. In her view, the only attempt to support her child's learning was through reading for brief periods of time in the evenings.

\section{Theme 3: Challenges with Learning from Home}

\section{Education and Job Uncertainty}

The uncertainty about a safe return to school and childcare along with reduced income forced many parents, mothers in particular, to stay home to supervise their children. This father's quote describes how his wife had no choice but to quit her job in order to take care of their children and supervise remote learning: "Mi esposa tuvo que dejar su trabajo. Como no teníamos quién nos ayudara con los nenes en la casa, ella tuvo que quedarse como mamá y maestra y todo. Entonces eso nos afectó en lo económico" (My wife had to quit her job. We didn't have childcare and therefore she had to stay home and take on the role of mom, teacher, and everything. This affected us financially).

Examples of how the pandemic has exacerbated the economic hardships faced by many families from lowincome backgrounds were abundant in parents' accounts. One mother expressed the despair of not having the means to cover basic expenses: "A veces no teníamos ni para los pañales...fue tan difícil, yo tuve que dejar de trabajar y a mi esposo le recortaron horas." (Sometimes we didn't have enough to buy diapers... it was really hard, I had to quit my job and my husband's work hours were reduced).

\section{Child's and Family Members' Mental Health}

The impact of the economic and health crisis on children and families' mental health was palpable in all interviews. About $75 \%$ of parents struggled with helping their children understand the need to stay home and worried about the prolonged social distancing impact on their children's socio-emotional well-being. Many parents shared how their children expressed frustration and a desire to go back to school. In sharing her concerns about her children's emotional health, a mother noted: "Mis hijos extrañaban mucho a sus compañeros y no entendían por qué no los podían ver. Fue triste, muy triste. ¿Pero qué se puede hacer? Esta pandemia nos afectó al cien." (My children missed their friends so much and didn't understand why they couldn't see them. It was sad, very sad. But what can we do? This pandemic has affected us one hundred percent).

\section{Learning from Home vs. Learning in the Classroom}

About $70 \%$ of parents expressed feeling stressed with distance learning. Parents believed that the transition to remote learning made the children feel as if school was over. When reflecting on her child 's lack of interest in remote learning, one mother expressed: "Había días que él no quería cooperar, se sentía que estaba de vacaciones y no quería saber nada de la escuela. Él no sentía que era tiempo de clase. Entonces sí batallamos" (Some days he didn't want to cooperate, he felt he was on vacation and didn't want to know anything related to school. He didn't feel that it was time for class. Thus, we struggled a lot).

Many parents attributed their child's loss of motivation to the change to remote education. In particular, parents voiced that learning from home was less conducive to young children's engagement. Despite feeling supported by teachers, parents repeatedly reported finding it difficult to engage their young children in school-based activities given the difference in dynamics and routines between the home and the school.

Parents also felt that they lacked the ability to maintain their young children focused and felt overburdened with the demands of remote learning. One mother shared her experience:

"Para uno que no es maestro, la paciencia es poca; los niños ya le conocen a uno el lado flaco. Yo le quise ayudar lo más que pude, pero estoy convencida de que no fue suficiente. Pero no es culpa del maestro, ni de los niños ni de los padres, porque uno no tiene la misma capacidad de enseñarles, uno no sabe cómo llegarles de la forma como les llegan los maestros" (For one who is not a teacher, we have little patience; children know our weak spots. I wanted to help her as much as I could, but I'm convinced that it wasn't enough. But it's not the teachers' fault, nor the children's or parents' fault because we don't have the same ability to teach them, we don't know how to engage them like teachers do). 


\section{Discussion}

This study examined how Latinx parents from low-income backgrounds perceived and applied teachers' suggested activities to support children's early education during the pandemic. We were also interested in documenting parent and child-initiated learning opportunities. Finally, we analyzed the challenges parents encountered with their child's remote learning.

Overall, parents reported engaging their children in the activities suggested by the teacher. Given the unusual circumstances brought by COVID-19 when parents had to assume the main responsibility for their children's education, parents were committed to their role as teacher at home. Parents created a variety of activities that they perceived as directly linked to the development of skills such as child's name writing, alphabet knowledge, phonemic awareness, recalling color names, handwriting and counting skills as suggested by teachers. These findings are contrary to previous reports suggesting that foreign-born Latinx parents provide less cognitive stimulation at home and engage their children less frequently in community activities designed for children's learning than U.S.-born White parents (Crosneo \& Ansari, 2015; Sonnenschein \& Galindo 2015). It is possible that the change to remote learning challenged parents' cultural models about their role in their children's education. Consequently, parents were obliged to undertake far more responsibility for their children's learning than before the pandemic. Previous studies document Latinx parents' deferential attitude towards teachers on academic matters as well as fear of causing confusion in their children by using methods they themselves learned in school (Olivos et al. 2011). One of the mothers of this study described her hesitancy in teaching the alphabet to her son:

"Compré un libro del abecedario y lo quería devolver porque mi esposo me dijo 'no, esto no va a servir; aquí les enseñan diferente. En mi país siempre empiezan con AEIOU y aquí no sé si empiezan con el abecedario.' Y yo dije, pues sí, tienes razón, porque tal vez yo lo voy a confundir. Mejor esperar a que el maestro nos diga" (I bought an ABC book and I wanted to return it because my husband said, "no, this won't work; here they teach differently. In my country they always start with the vowels first whereas here I don't know if they start with the alphabet." And I said, yes, you're right, because I may make it confusing for him. It's best to wait until the teacher tells us what to do).

Parent interviews also revealed that the teacher-suggested activities seemed to be congruent to the parents' cultural models for teaching literacy and mathematics. Parents demonstrated a preference for teaching from a skills-orientated perspective (Sonnenschein 1997), for example through exposing children to repeated practice in writing their name, identifying letters and numbers. Although these activities were motivated by teachers' suggestions, most parents expressed agreement with these recommendations.

In reflecting on how children responded to the type of activities suggested by the teacher, parents noticed that when the activities involved children's active participation, play, discovery, and choice, children showed greater motivation. As a result, parents initiated a host of experiences that engaged children in experiential learning such as cutting fruit and counting the number of slices or nature walks around the neighborhood. There were also descriptions of child-initiated activities such as playing doctor's office or bookstore where children enacted various roles along with literacy and mathematical practices they observe in their communities. These experiences seem to reflect an entertainment perspective and parents' attempts to be responsive to their child's interests (Sonnenschein, 1997). As researchers, it was difficult to obtain this type of information from parents (Gillanders \& Jimenez, 2004). Although we, as early educators, recognize the value of these experiences, we needed to prompt parents to describe these experiences as learning opportunities.

Cheadle and Amato (2011) use the term "concerted cultivation" to describe parents' deliberate efforts to promote children's cognitive and social emotional development. For example, parents intentionally engage their children in dance or music classes for the purpose of promoting their artistic development. Unlike Cheadle and Amato's (2011) study where they found Latinx parents showed less concerted cultivation than parents of other ethnicities and SES, we observed that parents in our study were intentional or made a concerted effort to implement the teacher-suggested activities. Parents made sure their children participated in activities that they viewed as preparation for kindergarten. At the same time, parents were responsive to children's interests and created various opportunities for children to be engaged, albeit being unaware of the educational value of those activities. While parent-initiated activities may not be visible to some teachers, they demonstrate parents' resourcefulness and commitment to their children's education. Since parentinitiated activities are seldomly represented in the classroom curriculum, parents seemed to be less conscious of its value for learning.

With regards to parental challenges, it was no surprise that parents without a college education were more likely to report greater financial struggles as many experienced reduced work hours or unemployment due to the pandemic. This mirrors the current situation of many Black and Latinx adults around the country without college degrees (Parker et al. 2020) who have indicated increased difficulty paying bills, having to dip into savings or borrow money, and 
use food banks to survive during the pandemic. A number of mothers in our study reported that in addition to losing employment they had to make the choice of staying at home to take care of their children and supervise remote learning. ECE teachers were instrumental in ameliorating families' economic struggles during the pandemic by connecting parents with community organizations that helped them with basic expenses and food supplies.

For this group of Latinx parents, supporting their children during remote learning was stressful. A major challenge reported by $75 \%$ of parents was that the children became unengaged and bored with the repeated practice of literacy and mathematical skills and with online lessons. Parents described that they had to "batallar" (battle) with their children to complete the teachers' assignments. Parents attributed their child's apathy for learning to the change to remote learning away from their peers and classroom routines, which made children feel that they were on "vacation." Also of note, parents reported feeling overburdened with the expectation of maintaining their young children interested in learning in addition to their existing responsibilities. Similar findings were found in a study conducted by Davis et al. (2020) who also reported elevated stress levels in parents with children struggling with remote learning. In addition, the vast majority of parents reported concern and helplessness about the impact of the pandemic on their children's socio-emotional well-being.

We expected language barriers to emerge as a challenge for parents when supporting their children's learning (Ramirez 2003); however, only one parent indicated having difficulties understanding the teachers' instructions. It is worth noting, however, that all foreign-born participants had lived more than 10 years in the U.S. Although the majority of the parents indicated that they spoke primarily Spanish at home, parents also reported some level of reading and writing in English. Furthermore, most of the focal children had older siblings, which allowed foreign-born parents to gain experience with U.S. schools. Finally, the majority of ECE programs the children attended used only Spanish or Spanish and English as language of instruction.

A limitation of this study is that given the mandated social distancing, we were not able to visit the families in their homes and conduct observations of their routines and practices. It is possible that parents engaged in additional practices with their children that they did not think about sharing. Furthermore, the small sample size raises the question of whether the experiences parents reported in this study are representative of other Latinx parents of young children during the pandemic. However, the purpose of the study was not to generalize what most Latinx parents believe or do. As other studies have found, there is great variability among the Latinx population (e.g., Davis et al. 2016). Our goal was to illuminate particular ways in which the pandemic can shape the home-school partnerships for some Latinx families.

\section{Conclusions and Implications for Practice}

We feel pride as ECE teacher educators that our colleagues rose to the challenge of this unprecedented time through authentic caring parent-teacher relationships. Parents were very appreciative of teachers' support and concern for their children's learning and family well-being. We believe and hope that this experience gives impetus to a positive change in the way teachers and parents interact when we return to "normal" times.

Establishing authentic home-school partnerships necessitates a stance towards "dialogic relationships" (Olivos et al. 2011; Poza et al. 2014) where teachers also learn about the parental academic socialization, cultural models and settings. This study shows how the remote learning demands during the pandemic has provided ECE teachers with a unique opportunity to learn more about children's lives outside of school and establish trusting relationships with parents. Moreover, the situation has required embracing a mindset that positions parents as equal partners in their children's education. Such dialogic collaboration can support ECE teachers to incorporate parents' practices as a resource for learning and make parents aware of the value of such practices.

As our interviews indicated, parents demonstrated extensive involvement in their children's remote education, revealing that they are committed to and capable of supporting their children's learning. An area where parents expressed needing support was in finding ways to make learning engaging for young children. Teacher education programs must prepare future teachers to explore families' sociocultural practices so that they can incorporate them in their curriculum and teaching (Gillanders et al. 2013; Reyes et al. 2016). Moreover, aspiring and current ECE teachers must be better equipped to create spaces and implement strategies that validate and make use of the families' sociocultural practices and promote play-based experiences.

Supplementary Information The online version contains supplementary material available at https://doi.org/10.1007/s10643-021-01210-4.

Acknowledgements We wish to thank Dr. Marina M. Mendoza, Director of Enrollment and Evaluation, Denver Preschool Program for partnering with us to conduct this study and to Dr. Lori Ryan for reviewing our manuscript and providing valuable insight.

Funding We also thank CU Denver's Office of Research Services (ORS) for awarding COVID-19 related funding to help supplement this study. 


\section{References}

Berube, A. (2020, May 14) What weekly unemployment claims reveal about the local impacts of the COVID-19 recession. Brookings Retrieved June 182020 from https://www.brookings.edu/blog/ the-avenue/2020/05/13/what-weekly-unemployment-claimsreveal-about-the-local-impacts-of-the-covid-19-recession/

Cheadle, J. E., \& Amato, P. R. (2011). A quantitative assessment of Lareau's qualitative conclusions about class, race, and parenting. Journal of Family Issues, 32(5), 679-706. https://doi.org/ 10.1177/0192513X10386305

Crosnoe, R., \& Ansari, A. (2015). Latin American immigrant parents and their children's teachers in US early childhood education programmes. International Journal of Psychology, 50(6), 431-439. https://doi.org/10.1002/ijop.12173

Davis, H. S., Gonzalez, J. E., Pollard-Durodola, S., Saenz, L. M., Soares, D. A., Resendez, N., Zhu, L., \& Hagan-Burke, S. (2016). Home literacy beliefs and practices among low-income Latino families. Early Child Development and Care, 186(7), 1152-1172. https://doi.org/10.1080/03004430.2015.1081184

Davis, C. R., Grooms, J., Ortega, A., Rubalcaba, J. A., \& Vargas, E. (2020). Distance learning and parental mental health during COVID-19. Educational Researcher, 50(1), 61-64. https://doi. org/10.3102/0013189X20978806

Gallimore, R., \& Goldenberg, C. (2001). Analyzing cultural models and settings to connect minority achievement and school improvement research. Educational Psychologist, 36(1), 45-56. https://doi.org/10.1207/S15326985EP3601_5

Gillanders, C., \& Jiménez, R. T. (2004). Reaching for success: a close-up of Mexican immigrant parents in the USA who foster literacy success for their kindergarten children. Journal of Early Childhood Literacy, 4(3), 243-269. https://doi.org/10. 1177/1468798404044513

Gillanders, C., Iruka, I., Bagwell, C., Morgan, J., \& García, S. (2013). Home and school partnerships: Raising children together. In S. Ritchie \& L. Gutman (Eds.), FirstSchool Transforming preK-3rd grade for African American Latino and lowincome children. Teachers College Press.

Glaser, B. G., \& Strauss, A. L. (1967) The discovery of grounded theory: Strategies for qualitative research. Chicago, IL: Aldine

Jeynes, W. (2003). A meta-analysis: the effects of parental involvement on minority children's academic achievement. Education and Urban Society, 35(2), 202-218. https://doi.org/10.1177/ 0013124502239392

Krostad, J. M., \& Lopez, M. H. (2020, August 4). Coronavirus economic downturn has hit Latinos especially hard. Pew Research Center, Hispanic Trends. Retrieved October 4, 2020, from https://www.pewresearch.org/hispanic/2020/08/04/coronaviruseconomic-downturn-has-hit-latinos-especially-hard/

Lynch, J., Anderson, J., Anderson, A., \& Shapiro, J. (2006). Parents' beliefs about young children's literacy development and parents' literacy behaviors. Reading Psychology, 27(1), 1-20. https://doi. org/10.1080/02702710500468708

Mistry, J., Li, J., Yoshikawa, H., Tseng, V., Tirrell, J., Kiang, L., Mistry, R., \& Wang, Y. (2016). An integrated conceptual framework for the development of Asian American children and youth. Child Development, 87(4), 1014-1032. https://doi.org/10.1111/ cdev. 12577

Moll, L. C., Amanti, C., Neff, D., \& Gonzalez, N. (1992). Funds of knowledge for teaching: using a qualitative approach to connect homes and classrooms. Theory into Practice, 31(2), 132-141.

Olivos EM, Jiménez-Castellanos O, \& Ochoa AM (Eds) (2011) Bicultural parent engagement: Advocacy and empowerment. New York, NY: Teachers College Press
Paris, D. (2012). Culturally sustaining pedagogy: a needed change in stance, terminology, and practice. Educational Researcher, 41(3), 93-97. https://doi.org/10.3102/0013189X12441244

Parker, K., Minkin, R. \& Bennett, J. (2020, September 24). Economic fallout from COVID-19 continues to hit lower-income Americans the hardest. Pew Research Center. Retrieved October 4, 2020, from https://www.pewsocialtrends.org/2020/09/24/econo mic-fallout-from-covid-19-continues-to-hit-lower-incomeamericans-the-hardest/

Pérez, M. S., \& Saavedra, C. M. (2017). A call for onto-epistemological diversity in early childhood education and care: centering global south conceptualizations of childhood/s. Review of Research in Education, 41(1), 1-29. https://doi.org/10.3102/ $0091732 X 16688621$

Poza, L., Brooks, M. D., \& Valdés, G. (2014). "Entre familia": immigrant parents' strategies for involvement in children's schooling. School Community Journal, 24(1), 119-148.

Puccioni, J. (2018). Parental beliefs about school readiness, home and school-based involvement, and children's academic achievement. Journal of Research in Childhood Education, 32(4), 435454. https://doi.org/10.1080/02568543.2018.1494065

Ramirez, A. F. (2003). Dismay and disappointment: parental involvement of Latino immigrant parents. The Urban Review, 35(2), 93-110. https://doi.org/10.1023/A:1023705511946

Rapid-EC Project (2020, June 2). Between a rock and a hard place. Rapid assessment of pandemic impact on development early childhood household survey project. Retrieved July 18, 2020, fromhttps://medium.com/rapid-ec-project/between-a-rock-anda-hard-place-245857e79d9d

Reese, L., \& Gallimore, R. (2000). Immigrant Latino's cultural model of literacy development: an evolving perspective on home-school discontinuities. American Journal of Education, 108(2), 103-134. https://doi.org/10.1086/444236

Reyes, I., Da Silva Iddings, A. C., \& Feller, N. (2016). Building relationships with diverse students and families: a funds of knowledge perspective. Journal of Early Childhood Literacy, 16(1), 8-33. https://doi.org/10.1177/1468798415584692

Rodriguez, M. V. (2006). Language and literacy practices in Dominican families in New York City. Early Child Development and Care, 176(2), 171-182. https://doi.org/10.1080/0300443050 0040117

Rogoff, B. (2003). The cultural nature of human development. New Yor, NY: Oxford University Press.

Smith, T. E., Sheridan, S. M., Kim, E. M., Park, S., \& Beretvas, S. N. (2020). The effects of family-school partnership interventions on academic and social-emotional functioning: a meta-analysis exploring what works for whom. Educational Psychology Review, 32(2), 511-544. https://doi.org/10.1007/s10648-019-09509-w

Sonnenschein, S., \& Galindo, C. (2015). Race/ethnicity and early mathematics skills: relations between home, classroom, and mathematics achievement. The Journal of Educational Research, 108(4), 261-277. https://doi.org/10.1080/00220671.2014.880394

Sonnenschein, S., Baker, L., Serpell, R., Scher, D., Truitt, V., \& Munsterman, K. (1997). Parental beliefs about ways to help children learn to read: the impact of an entertainment or a skills perspective. Early Child Development and Care, 127(1), 111-118. https:// doi.org/10.1080/0300443971270109

Sonnenschein, S., Galindo, C., Simons, C. L., Metzger, S. R., Thompson, J. A., \& Chung, M. (2018). How do children learn mathematics? Chinese and Latina immigrant perspectives. In S. S. Chuang \& C. L. Costigan (Eds.), Parental roles and relationships in immigrant families: An international approach (pp. 111-128). Business Media: Springer Science.

Suizzo, M. A., Pahlke, E., Yarnell, L., Chen, K. Y., \& Romero, S. (2014). Home-based parental involvement in young children's learning across US ethnic groups: cultural models of academic 
socialization. Journal of Family Issues, 35(2), 254-287. https:// doi.org/10.1177/0192513X12465730

Taylor, L. C., Clayton, J. D., \& Rowley, S. J. (2004). Academic socialization: understanding parental influences on children's schoolrelated development in the early years. Review of General Psychology, 8(3), 163-178. https://doi.org/10.1037/1089-2680.8.3. 163
Yin R.K. (2009). Case study research: Design and methods $\left(4^{\text {th }}\right.$ ed). Thousand Oaks, CA: Sage

Publisher's Note Springer Nature remains neutral with regard to jurisdictional claims in published maps and institutional affiliations. 